\title{
Research Progress on the Separation of Alkaloids from Chinese Medicines by Column Chromatography
}

\author{
Yaqin He*, Zhaozeng Chen*, Haibin Qu, Xingchu Gong\# \\ Pharmaceutical Informatics Institute, College of Pharmaceutical Sciences, Zhejiang University, Hangzhou, China \\ Email: "gongxingchu@zju.edu.cn
}

How to cite this paper: He, Y.Q., Chen, Z.Z., Qu, H.B. and Gong, X.C. (2020) Research Progress on the Separation of Alkaloids from Chinese Medicines by Column Chromatography. Advances in Chemical Engineering and Science, 10, 358-377. https://doi.org/10.4236/aces.2020.104023

Received: July 24, 2020

Accepted: September 15, 2020

Published: September 18, 2020

Copyright $\odot 2020$ by author(s) and Scientific Research Publishing Inc. This work is licensed under the Creative Commons Attribution International License (CC BY 4.0).

http://creativecommons.org/licenses/by/4.0/

\begin{abstract}
Alkaloids have a variety of bioactivities and great development value in the fields of pharmaceuticals, cosmetics and health food. Column chromatography is a common method for preparing alkaloids. In this paper, the research status of the separation and purification of alkaloids from Chinese medicines by column chromatography is reviewed, and the factors that influence the refining of alkaloids via a macroporous adsorption resin, ion exchange resin and silica gel are summarized. The thermodynamic and kinetic modeling methods for the static adsorption of adsorbents are also reviewed in this paper. It is suggested that the modeling method of the column chromatography process be deeply studied to establish a more stringent quality control method for sampling liquid and to strengthen the online detection of the chromatography process to improve the refining effect of alkaloids.
\end{abstract}

\section{Keywords}

Alkaloid, Column Chromatography, Ion Exchange Resin,

Macroporous Adsorbent Resin, Model, Silica Gel

\section{Introduction}

Alkaloids are widely found in higher plants on land, especially in Caryophyllaceae, Annonaceae, Apocynaceae, Compositae, Berberidaceae, Boraginaceae, Buxaceae and other plants, but less frequently in lower plants and animals. Alkaloids are natural secondary metabolites that are generally synthesized through the biosynthetic amino acid pathway and the mevalonic acid (isoprene) pathway [1].

*These authors contributed equally to this work. 
Alkaloids have many bioactivities, such as asthmatic, cough relief, antimicrobial, anti-inflammatory, anti-tumor and other properties [2] [3] [4]. They have a great development value in the fields of pharmaceuticals, health food and cosmetics. The commonly used preparation methods are precipitation, extraction and chromatography. The fillers commonly used in chromatography include macroporous resins, ion exchange resins and silica gels, in addition to the use of alumina. Chromatography is a powerful separation method for natural products including alkaloids. The establishment of chromatographic models is also important to design and optimize the chromatographic processes. In this paper, the research progress in recent years will be summarized from the perspective of different types of chromatographic fillers and modeling methods of the chromatographic process.

\section{Macroporous Resins}

\subsection{Properties of Macroporous Resin}

Macroporous resins, as organic polymer adsorbents, generally have a macroporous network structure and large specific surface area. The macroporous resin does not contain exchange groups. The resin adsorbs molecules through van der Waals force, and the molecules are separated and purified after being eluted by a certain eluent. The physical properties of macroporous adsorption resins commonly used in alkaloid refining are summarized in Table 1. Some of their photos are shown in Figure 1. D-101 is opalescent spherical particles with a wide size distribution. The diameter values of some particles are larger than $1 \mathrm{~mm}$. Compared with D-101, the particle diameter of HPD-100 or D-151 is smaller and more uniform. $001 \times 7$ are golden transparent spherical particles, and the particle diameter distribution is relatively narrow.

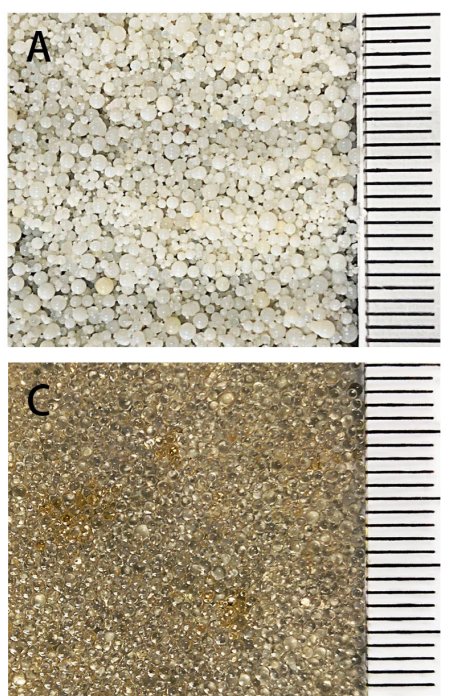

A: D-101

B: HPD-100

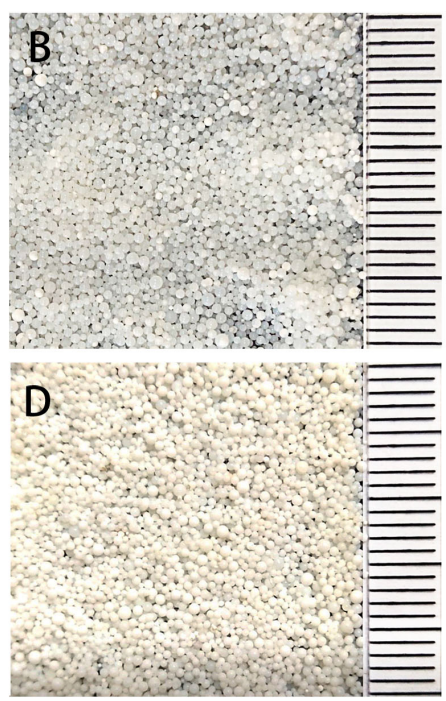

C: $001 \times 7$

D: D-151 
Table 1. Physical properties of the macroporous resins used in alkaloid refining.

\begin{tabular}{cccccc}
\hline Name & Polarity & Pore Diameter $(\mathrm{nm})$ & Particle Diameter $(\mathrm{mm})$ & Surface Area $\left(\mathrm{m}^{2} \cdot \mathrm{g}^{-1}\right)$ & Reference \\
\hline AB-8 & Weakly polar & $13-14$ & $0.3-1.25$ & $480-520$ & {$[5]$} \\
BS-65 & Nonpolar & 7 & $0.25-0.83$ & $580-600$ & {$[6]$} \\
D-101 & Nonpolar & $9-10$ & $0.25-0.83$ & $480-520$ & {$[6]$} \\
D-3520 & Nonpolar & $8.5-9$ & $0.3-1.25$ & $480-520$ & {$[5]$} \\
HPD-100 & Nonpolar & $8.5-9$ & $0.3-1.25$ & $650-700$ & {$[7]$} \\
NKA-9 & Polar & $15-16.5$ & $0.3-1.25$ & $250-290$ & {$[5]$} \\
XAD-4 & Nonpolar & 5.8 & $0.49-0.69$ & 750 & {$[8]$} \\
X-5 & Nonpolar & $29-30$ & $0.3-1.25$ & $500-600$ & {$[9]$}
\end{tabular}

As presented in Table 1, the nonpolar or weakly polar macroporous resins are more widely used in the separation and purification of alkaloids than the polar macroporous resins. Table 2 lists the resins used by researchers in China and abroad in the separation of alkaloids. Table 2 shows that many researchers are more likely to use HPD-100, D-101, and AB-8 macroporous resins. The common characteristics of the three resins are that the specific surface area is greater than $480 \mathrm{~m}^{2} \cdot \mathrm{g}^{-1}$, the pore diameter is in the range of 8 to $14 \mathrm{~nm}$ and the particle diameter is in the range of $0.25-1.25 \mathrm{~mm}$. A larger particle diameter is beneficial to reduce the liquid pressure in the chromatography process.

\subsection{Chromatography Process}

The basic process of refining the alkaloids of Chinese medicines with a macroporous resin is as follows: resin pretreatment, sample loading, washing, elution, and resin regeneration. Table 2 lists the sample loading, washing, and elution conditions and refining results reported in the literature.

\subsubsection{Sample Loading}

The main factors affecting the sample loading process are the properties of the loading solution, the loading solution volume, and the flow rate of sample loading. Table 2 shows that most of the work was performed with a water solution. The $\mathrm{pH}$ value of the loading solution has a great influence on the adsorption effect [9] [10], and many researchers controlled the $\mathrm{pH}$ value of the loading solution to be alkaline [9] [11]. In an alkaline solution, alkaloids often exist in molecular form, which is more favorable for macroporous resin adsorption. In general, a high concentration, large volume, and fast loading speed of the loading solution are more likely to lead to the leakage of alkaloids at the outlet of the chromatographic column. Most researchers controlled the sample loading speed to between 1 and $6 \mathrm{BV} \cdot \mathrm{h}^{-1}$ [9] [12]. Some researchers controlled the loading volume according to the leakage of alkaloids in the liquid at the outlet of the chromatographic column [5] [9]. Compared with loading a fixed volume of the sample, this method enabled researchers to make full use of the adsorption capacity of the resin in the column. 
Table 2. Study on the separation and purification of alkaloids from traditional Chinese medicine by macroporous resins.

\begin{tabular}{|c|c|c|c|c|c|c|c|c|c|c|c|c|}
\hline \multirow{2}{*}{$\begin{array}{l}\text { Name of } \\
\text { Chinese } \\
\text { medicine }\end{array}$} & \multirow{2}{*}{$\begin{array}{l}\text { Names } \\
\text { of } \\
\text { alkaloids }\end{array}$} & \multirow{2}{*}{ Type of resin } & \multicolumn{2}{|c|}{ Sample loading } & \multicolumn{3}{|l|}{ Washing } & \multicolumn{2}{|l|}{ Elution } & \multirow[b]{2}{*}{ Purity } & \multirow{2}{*}{ Recovery } & \multirow{2}{*}{ Reference } \\
\hline & & & $\begin{array}{l}\text { the } \\
\text { sample }\end{array}$ & Flow rate & Type & Flow rate & volume & $\begin{array}{l}\text { Type and } \\
\text { volume }\end{array}$ & Flow rate & & & \\
\hline $\begin{array}{l}\text { Corydalis } \\
\text { yanhusuo W.T. } \\
\text { Wang }\end{array}$ & $\begin{array}{l}\text { total } \\
\text { alkaloids }\end{array}$ & HPD-100 & & $2 \mathrm{BV} \cdot \mathrm{h}^{-1}$ & water & $3 \mathrm{BV} \cdot \mathrm{h}^{-1}$ & $\begin{array}{l}\text { wash to } \\
\text { neutral }\end{array}$ & $\begin{array}{l}60 \% \text { ethanol } \\
5 \mathrm{BV} \\
80 \% \text { ethanol } \\
1 \mathrm{BV}\end{array}$ & $3 \mathrm{BV} \cdot \mathrm{h}^{-1}$ & & & [12] \\
\hline $\begin{array}{l}\text { Sophora } \\
\text { flavescens }\end{array}$ & matrine, oxymatrine & H103 & & & nothing & & & $\begin{array}{l}30 \% \\
\text { ethanol-25\% } \\
\text { ammonia water } \\
(115: 1) \\
80 \% \text { ethanol }\end{array}$ & & & $\begin{array}{l}\text { matrine: } \\
90.1 \% \text {, } \\
\text { oxymatrine: } \\
85.3 \%\end{array}$ & [30] \\
\hline $\begin{array}{l}\text { Gelsemium } \\
\text { elegans Benth. } \\
\text { root }\end{array}$ & $\begin{array}{l}\text { total } \\
\text { alkaloids }\end{array}$ & AB-8 & & & water & & & $\begin{array}{l}90 \% \text { ethanol } \\
4 \mathrm{BV}\end{array}$ & $\begin{array}{l}1-2 \\
\mathrm{~mL} \cdot \mathrm{min}^{-1}\end{array}$ & $5.54 \%$ & & [26] \\
\hline $\begin{array}{l}\text { Sophora } \\
\text { alopecuroides } \\
\text { Linn }\end{array}$ & $\begin{array}{l}\text { total } \\
\text { alkaloids }\end{array}$ & D-101 & 9 & $5 \mathrm{BV} \cdot \mathrm{h}^{-1}$ & nothing & & & $\begin{array}{l}30 \% \text { ethanol } \\
3 \mathrm{BV} \\
70 \% \text { ethanol } \\
3 \mathrm{BV}\end{array}$ & $1.0 \mathrm{BV} \cdot \mathrm{h}^{-1}$ & $66.75 \%$ & & [9] \\
\hline $\begin{array}{l}\text { Sophora } \\
\text { alopecuroides }\end{array}$ & $\begin{array}{l}\text { total } \\
\text { alkaloids }\end{array}$ & D-101 & 9 & & nothing & & & $\begin{array}{l}30 \% \text { ethanol } \\
(\mathrm{pH}=9) 210 \mathrm{~mL} \\
70 \% \text { ethanol } \\
(\mathrm{pH}=9) 210 \mathrm{~mL}\end{array}$ & & over $60 \%$ & $>97 \%$ & [11] \\
\hline Hyoscyami Semen & $\begin{array}{l}\text { total } \\
\text { alkaloids }\end{array}$ & LSA-5B & & $1.5 \mathrm{BV} \cdot \mathrm{h}^{-1}$ & water & $\begin{array}{l}1.5 \\
\mathrm{BV} \cdot \mathrm{h}^{-1}\end{array}$ & $4 \mathrm{BV}$ & $\begin{array}{l}50 \% \text { ethanol } \\
10 \mathrm{BV}\end{array}$ & $1.5 \mathrm{BV} \cdot \mathrm{h}^{-1}$ & $4.02 \%$ & & [13] \\
\hline \multirow{5}{*}{$\begin{array}{l}\text { Zanthoxylum } \\
\text { nitidum (Roxb.) } \\
\text { DC }\end{array}$} & \multirow{5}{*}{$\begin{array}{l}\text { total } \\
\text { alkaloids }\end{array}$} & \multirow{5}{*}{ D-101 } & & $4 \mathrm{BV} \cdot \mathrm{h}^{-1}$ & nothing & & & $\begin{array}{l}\text { The first time: } \\
95 \% \text { ethanol } \\
4 \mathrm{BV}\end{array}$ & $2 \mathrm{BV} \cdot \mathrm{h}^{-1}$ & \multirow{5}{*}{$27.67 \%$} & & \multirow{5}{*}{ [31] } \\
\hline & & & & & nothing & & & $\begin{array}{l}\text { The second time: } \\
95 \% \text { ethanol } \\
3 \mathrm{BV}\end{array}$ & $2 \mathrm{BV} \cdot \mathrm{h}^{-1}$ & & & \\
\hline & & & & $4 \mathrm{BV} \cdot \mathrm{h}^{-1}$ & nothing & & & $\begin{array}{l}\text { The first time: } \\
80 \% \text { ethanol } \\
3 \mathrm{BV}\end{array}$ & $4 \mathrm{BV} \cdot \mathrm{h}^{-1}$ & & & \\
\hline & & & & & nothing & & & $\begin{array}{l}\text { The second time: } \\
80 \% \text { ethanol } \\
2 \text { BV }\end{array}$ & $4 \mathrm{BV} \cdot \mathrm{h}^{-1}$ & & & \\
\hline & & & & $4 \mathrm{BV} \cdot \mathrm{h}^{-1}$ & $\begin{array}{l}\mathrm{HCl} \\
(\mathrm{pH}=5)\end{array}$ & & $1 \mathrm{BV}$ & $\begin{array}{l}50 \% \text { ethanol } \\
4 \mathrm{BV}\end{array}$ & $2 \mathrm{BV} \cdot \mathrm{h}^{-1}$ & & & \\
\hline $\begin{array}{l}\text { Colchicum } \\
\text { autumnale } \mathrm{L} .\end{array}$ & $\begin{array}{l}\text { total } \\
\text { alkaloids }\end{array}$ & LSA-5B & 2.5 & $1.5 \mathrm{BV} \cdot \mathrm{h}^{-1}$ & water & & $8 \mathrm{BV}$ & $\begin{array}{l}70 \% \text { ethanol } \\
20 \mathrm{BV}\end{array}$ & $1.5 \mathrm{BV} \cdot \mathrm{h}^{-1}$ & $12.41 \%$ & $62.27 \%$ & [10] \\
\hline Lotus leaves & $\begin{array}{l}\text { total } \\
\text { alkaloids }\end{array}$ & D-101 & & $3 \mathrm{BV} \cdot \mathrm{h}^{-1}$ & nothing & & & $\begin{array}{l}90 \% \text { ethanol } \\
4 \mathrm{BV}\end{array}$ & $1.5 \mathrm{BV} \cdot \mathrm{h}^{-1}$ & & $57.2 \%$ & [32] \\
\hline $\begin{array}{l}\text { Peels of Carya } \\
\text { cathayensis Sarg. }\end{array}$ & $\begin{array}{l}\text { total } \\
\text { alkaloids }\end{array}$ & NKA-9 & 7.0 & $2 \mathrm{BV} \cdot \mathrm{h}^{-1}$ & $\begin{array}{l}\text { water } \\
2 \mathrm{BV} \\
30 \% \\
\text { ethanol } \\
2 \mathrm{BV}\end{array}$ & & $4 \mathrm{BV}$ & $\begin{array}{l}70 \% \text { ethanol } \\
4 \mathrm{BV}\end{array}$ & $2 \mathrm{BV} \cdot \mathrm{h}^{-1}$ & $5.27 \%$ & & [14] \\
\hline $\begin{array}{l}\text { Sophora } \\
\text { flavescens }\end{array}$ & $\begin{array}{l}\text { total } \\
\text { alkaloids }\end{array}$ & $X-5$ & 10 & $6 \mathrm{BV} \cdot \mathrm{h}^{-1}$ & water & $2.5 \mathrm{BV} \cdot \mathrm{h}^{-1}$ & $5 \mathrm{BV}$ & $\begin{array}{l}60 \% \text { ethanol } \\
(\mathrm{pH}=1)\end{array}$ & $2.5 \mathrm{BV} \cdot \mathrm{h}^{-1}$ & $39.98 \%$ & & [19] \\
\hline Lotus leaves & $\begin{array}{l}\text { total } \\
\text { alkaloids }\end{array}$ & HPD-100 & $5-6$ & 2 & $\begin{array}{l}\text { water } \\
10 \mathrm{BV} \\
30 \% \\
\text { methanol } \\
5 \mathrm{BV}\end{array}$ & & $15 \mathrm{BV}$ & $\begin{array}{l}75 \% \text { methanol } \\
20 \mathrm{BV}\end{array}$ & & & & {$[15]$} \\
\hline $\begin{array}{l}\text { Macleaya } \\
\text { cordata (Willd) R. } \\
\text { Br. }\end{array}$ & rotopine alkaloids & AB-8 & 8 & $\begin{array}{l}1 \\
\mathrm{~mL} \cdot \mathrm{min}^{-1}\end{array}$ & water & & $1 \mathrm{BV}$ & $\begin{array}{l}90 \% \text { ethanol } \\
3 \mathrm{BV}\end{array}$ & $\begin{array}{l}1 \\
\mathrm{~mL} \cdot \mathrm{min}^{-1}\end{array}$ & $>90 \%$ & & [33] \\
\hline Lotus leaves & $\begin{array}{l}\text { total } \\
\text { alkaloids }\end{array}$ & D-101 & & & water & & $3-5 \mathrm{BV}$ & $\begin{array}{l}20 \% \text { ethanol } \\
2 \mathrm{BV} \\
40 \% \text { ethanol } \\
2 \mathrm{BV} \\
60 \% \text { ethanol } \\
2 \mathrm{BV} \\
80 \% \text { ethanol } \\
2 \mathrm{BV}\end{array}$ & $\begin{array}{l}1.50 \\
\mathrm{BV} \cdot \mathrm{h}^{-1}\end{array}$ & $32.56 \%$ & $62.9 \%$ & [34] \\
\hline
\end{tabular}




\section{Continued}

\begin{tabular}{|c|c|c|c|c|c|c|c|c|c|c|c|c|}
\hline $\begin{array}{l}\text { Coptis } \\
\text { chinensis Franch }\end{array}$ & $\begin{array}{l}\text { total } \\
\text { alkaloids }\end{array}$ & AB-8 & & & water & $1 \mathrm{BV} \cdot \mathrm{h}^{-1}$ & $2 \mathrm{BV}$ & $\begin{array}{l}40 \% \text { ethanol } \\
2 \mathrm{BV}\end{array}$ & $1 \mathrm{BV} \cdot \mathrm{h}^{-1}$ & $80 \%$ & & [21] \\
\hline $\begin{array}{l}\text { Fritillaria } \\
\text { hupehensis Hsiao } \\
\text { et K.C.H sia }\end{array}$ & $\begin{array}{l}\text { total } \\
\text { alkaloids }\end{array}$ & D-101 & 9 & $2 \mathrm{BV} \cdot \mathrm{h}^{-1}$ & water & $2 \mathrm{BV} \cdot \mathrm{h}^{-1}$ & $8 \mathrm{BV}$ & $\begin{array}{l}50 \% \text { ethanol } \\
4 \mathrm{BV}\end{array}$ & $2 \mathrm{BV} \cdot \mathrm{h}^{-1}$ & $74.20 \%$ & & [35] \\
\hline $\begin{array}{l}\text { Plumula } \\
\text { nelumbinis }\end{array}$ & neferine & LSA-5B & & $2 \mathrm{BV} \cdot \mathrm{h}^{-1}$ & water & $2 \mathrm{BV} \cdot \mathrm{h}^{-1}$ & & $50 \%$ ethanol & $2 \mathrm{BV} \cdot \mathrm{h}^{-1}$ & $3.50 \%$ & $91.62 \%$ & [28] \\
\hline $\begin{array}{l}\text { Macleaya } \\
\text { cordata } \\
\text { (Willd) R. Br. }\end{array}$ & $\begin{array}{l}\text { total } \\
\text { alkaloids }\end{array}$ & AB- 8 & $7-8$ & $\begin{array}{l}2-3 \\
\mathrm{~mL} \cdot \min ^{-1}\end{array}$ & water & $\begin{array}{l}3-4 \\
\mathrm{~mL} \cdot \mathrm{min}^{-1}\end{array}$ & $4 \mathrm{BV}$ & $\begin{array}{l}90 \% \text { ethanol } \\
2-3 \mathrm{BV}\end{array}$ & $\begin{array}{l}2-3 \\
\mathrm{~mL} \cdot \min ^{-1}\end{array}$ & $>90 \%$ & $91.24 \%$ & [36] \\
\hline Lotus leaves & $\begin{array}{l}\text { aporphine } \\
\text { alkaloids }\end{array}$ & HPD-100 & & & water & $\begin{array}{l}7.5 \\
\mathrm{~mL} \cdot \mathrm{min}^{-1}\end{array}$ & $5 \mathrm{BV}$ & $\begin{array}{l}70 \% \\
\text { methanol } \\
5 \mathrm{BV} \\
80 \% \\
\text { methanol } \\
10 \mathrm{BV} \\
95 \% \\
\text { methanol } \\
10 \mathrm{BV}\end{array}$ & $\begin{array}{l}7.5 \\
\mathrm{~mL} \cdot \mathrm{min}^{-1}\end{array}$ & $\begin{array}{l}\text { nuciferine: } \\
68.52 \% \\
\text { N-nornuciferine: } \\
44.01 \% \\
\text { O-nornuciferine: } \\
7.61 \%\end{array}$ & & [16] \\
\hline & & & & & & & & $\begin{array}{l}30 \% \text { ethanol } \\
15 \mathrm{~mL}\end{array}$ & & & & \\
\hline Gelsemium elegans & & & & & & & & $50 \%$ ethanol & & & & \\
\hline $\begin{array}{l}\text { (Gardn. \& } \\
\text { Champ.) } \\
\text { Benth. }\end{array}$ & $\begin{array}{l}\text { total } \\
\text { alkaloids }\end{array}$ & HPD-800 & 11 & & water & & $20 \mathrm{~mL}$ & $\begin{array}{l}15 \mathrm{~mL} \\
70 \% \text { ethanol } \\
15 \mathrm{~mL} \\
95 \% \text { ethanol } \\
15 \mathrm{~mL}\end{array}$ & & $95.32 \%$ & & [24] \\
\hline Ephedra & ephedrine & FXD-1 & $10-11$ & $\begin{array}{l}3.0 \\
\mathrm{~mL} \cdot \mathrm{min}^{-1}\end{array}$ & nothing & & & $\begin{array}{l}0.08 \mathrm{~mol} / \mathrm{L} \text { oxalic } \\
\text { acid }\end{array}$ & $\begin{array}{l}3.0 \\
\mathrm{~mL} \cdot \mathrm{min}^{-1}\end{array}$ & $91.20 \%$ & $99.3 \%$ & [17] \\
\hline $\begin{array}{l}\text { Corydalis } \\
\text { yanhusuo W.T. } \\
\text { Wang }\end{array}$ & $\begin{array}{l}\text { total } \\
\text { alkaloids }\end{array}$ & NKA-9 & & & water & $2 \mathrm{BV} \cdot \mathrm{h}^{-1}$ & $5 \mathrm{BV}$ & $\begin{array}{l}70 \% \text { ethanol } \\
12 \mathrm{BV}\end{array}$ & $1.5 \mathrm{BV} \cdot \mathrm{h}^{-1}$ & $>50 \%$ & & [37] \\
\hline $\begin{array}{l}\text { Lateral Root } \\
\text { of Aconitum } \\
\text { carmichaelii }\end{array}$ & $\begin{array}{l}\text { diterpenoid } \\
\text { alkaloids }\end{array}$ & HPD-110 & & & water & & $50 \mathrm{~L}$ & $\begin{array}{l}30 \% \text { ethanol } \\
120 \mathrm{~L} \\
50 \% \text { ethanol } \\
120 \mathrm{~L} \\
95 \% \text { ethanol } \\
100 \mathrm{~L}\end{array}$ & & & & [25] \\
\hline $\begin{array}{l}\text { Nitraria } \\
\text { sibirica leaves }\end{array}$ & $\begin{array}{l}\text { total } \\
\text { alkaloids }\end{array}$ & HPD-450 & & & water & & & $50 \%$ ethanol & & $18.08 \%$ & & [38] \\
\hline $\begin{array}{l}\text { Chelidonium } \\
\text { majus }\end{array}$ & chelidonine & D101 & & $6 \mathrm{BV} \cdot \mathrm{h}^{-1}$ & water & $6 \mathrm{BV} \cdot \mathrm{h}^{-1}$ & $2 \mathrm{BV}$ & $\begin{array}{l}30 \% \text { ethanol } \\
5 \mathrm{BV} \\
80 \% \text { ethanol } \\
14 \mathrm{BV}\end{array}$ & $6 \mathrm{BV} \cdot \mathrm{h}^{-1}$ & $37.81 \%$ & $80.77 \%$ & [39] \\
\hline $\begin{array}{l}\text { Stephania } \\
\text { cepharantha } \\
\text { Hayata }\end{array}$ & $\begin{array}{l}\text { total } \\
\text { alkaloids }\end{array}$ & D101 & & & nothing & & & $\begin{array}{l}\text { ethanol-water- } \\
\text { triethylamine } \\
(30: 65: 5) \\
\text { ethanol-water- } \\
\text { formic acid } \\
(70: 25: 5) \\
95 \% \text { ethanol } \\
10 \mathrm{BV} \text { (in total) }\end{array}$ & & $3.4 \%$ & & [40] \\
\hline $\begin{array}{l}\text { Huperzia } \\
\text { serrata }\end{array}$ & $\begin{array}{l}\text { huperzine- } A \text { and } \\
\text { huperzine- } B\end{array}$ & SP850 & 9.0 & $5 \mathrm{BV} \cdot \mathrm{h}^{-1}$ & water & & $6 \mathrm{BV}$ & $\begin{array}{l}10 \% \text { ethanol } \\
3 \mathrm{BV} \\
70 \% \text { ethanol } \\
6 \mathrm{BV} \\
\text { pure ethanol } \\
3 \mathrm{BV}\end{array}$ & $5 \mathrm{BV} \cdot \mathrm{h}^{-1}$ & $\begin{array}{l}\text { huperzine-A: } \\
2.03 \% \\
\text { huperzine-B: } \\
0.91 \%\end{array}$ & $\begin{array}{l}\text { huperzine-A: } \\
90.1 \% \\
\text { huperzine-B: } \\
93.2 \%\end{array}$ & [29] \\
\hline $\begin{array}{l}\text { Fritillaria } \\
\text { cirrhosa }\end{array}$ & $\begin{array}{l}\text { total } \\
\text { alkaloids }\end{array}$ & H103 & 7.0 & $4 \mathrm{BV} \cdot \mathrm{h}^{-1}$ & water & $2 \mathrm{BV} \cdot \mathrm{h}^{-1}$ & $8 \mathrm{BV}$ & $\begin{array}{l}10 \% \text { ethanol } \\
4 \mathrm{BV} \\
90 \% \text { ethanol } \\
6 \mathrm{BV}\end{array}$ & $2 \mathrm{BV} \cdot \mathrm{h}^{-1}$ & & $94.43 \%$ & [27] \\
\hline $\begin{array}{l}\text { Sophora } \\
\text { alopecuroides }\end{array}$ & $\begin{array}{l}\text { matrine, } \\
\text { oxymatrine, } \\
\text { and } \\
\text { sophoridine }\end{array}$ & AB- 8 & 10 & $2 \mathrm{BV} \cdot \mathrm{h}^{-1}$ & water & & & $\begin{array}{l}80 \% \text { ethanol } \\
5 \mathrm{BV}\end{array}$ & $2 \mathrm{BV} \cdot \mathrm{h}^{-1}$ & $\begin{array}{l}\text { matrine: } 22.22 \% \\
\text { oxymatrine: } \\
21.44 \% \\
\text { sophoridine: } \\
28.02 \%\end{array}$ & $\begin{array}{l}\text { matrine: } \\
69.4 \% \\
\text { oxymatrine: } \\
78.3 \% \\
\text { sophoridine: } \\
72.6 \%\end{array}$ & [7] \\
\hline
\end{tabular}




\section{Continued}

\begin{tabular}{|c|c|c|c|c|c|c|c|c|c|c|c|c|}
\hline $\begin{array}{l}\text { Aconiti } \\
\text { kusnezoffii } \\
\text { radix }\end{array}$ & $\begin{array}{l}\text { aconitine, } \\
\text { mesaconitine, } \\
\text { hypaconitine, } \\
\text { benzoylaconine, } \\
\text { benzoylmesaconine, } \\
\text { and } \\
\text { benzoylhypaconine }\end{array}$ & NKA-II & 6 & $1 \mathrm{BV} \cdot \mathrm{h}^{-1}$ & $\begin{array}{l}\text { water } \\
2.8 \mathrm{BV} \\
35 \% \\
\text { ethanol } \\
2.8 \mathrm{BV}\end{array}$ & $1 \mathrm{BV} \cdot \mathrm{h}^{-1}$ & $5.6 \mathrm{BV}$ & $\begin{array}{l}95 \% \text { ethanol } \\
(\mathrm{pH}=2) \\
3.3 \mathrm{BV}\end{array}$ & $1 \mathrm{BV} \cdot \mathrm{h}^{-1}$ & $\begin{array}{l}\text { total alkaloids: } \\
60.3 \%\end{array}$ & $75.8 \%$ & [18] \\
\hline $\begin{array}{l}\text { Dicranostigma } \\
\text { leptopodum } \\
\text { (Maxim.) } \\
\text { Fedde }\end{array}$ & total alkaloids & D101 & $6-7$ & $1 \mathrm{BV} \cdot \mathrm{h}^{-1}$ & water & & $4 \mathrm{BV}$ & $\begin{array}{l}70 \% \text { ethanol } \\
10 \mathrm{BV}\end{array}$ & $2 \mathrm{BV} \cdot \mathrm{h}^{-1}$ & $(65.92 \pm 1.33) \%$ & & [41] \\
\hline $\begin{array}{l}\text { Camellia } \\
\text { ptilophylla }\end{array}$ & theobromine & XAD-16 & & $\begin{array}{l}0.75 \\
B V \cdot h^{-1}\end{array}$ & water & & $8 \mathrm{BV}$ & $20 \%$ ethanol & & $74 \%$ & & [22] \\
\hline Toad venom & crude alkaloids & D101 & & & water & & & $5 \%$ ethanol & & & & [23] \\
\hline Pepper & capsaicin & SKP-10-4300 & 8 & $1.0 \mathrm{BV} \cdot \mathrm{h}^{-1}$ & water & & $2 \mathrm{BV}$ & $\begin{array}{l}20 \% \text { ethanol } \\
2 \mathrm{BV} \\
45 \% \text { ethanol } \\
2 \mathrm{BV} \\
45 \% \\
\text { ethanol-55\% } \\
\text { sodium } \\
\text { hydroxide } \\
\text { solution } \\
(1 \%, \mathrm{w} / \mathrm{w}) 8 \mathrm{BV}\end{array}$ & $1.0 \mathrm{BV} \cdot \mathrm{h}^{-1}$ & $92 \%$ & $85 \%$ & [20] \\
\hline $\begin{array}{l}\text { Folium } \\
\text { isatidis }\end{array}$ & $\begin{array}{l}\text { indigotin } \\
\text { and indirubin }\end{array}$ & D3520 & & $\begin{array}{l}1 \\
\mathrm{BV} \cdot \mathrm{h}^{-1}\end{array}$ & water & & & $\begin{array}{l}50 \% \text { ethanol } \\
13 / 3 \mathrm{BV} \\
\text { pure ethanol } \\
16 / 3 \mathrm{BV}\end{array}$ & $3 \mathrm{BV} \cdot \mathrm{h}^{-1}$ & $\begin{array}{l}\text { indigotin: } 4.73 \% \\
\text { indirubin: } 8.99 \%\end{array}$ & & [5] \\
\hline $\begin{array}{l}\text { Sophora } \\
\text { flavescens }\end{array}$ & $\begin{array}{l}\text { matrine and } \\
\text { oxymatrine }\end{array}$ & BS-65 & 10 & $\begin{array}{l}2 \\
\mathrm{~mL} \cdot \mathrm{min}^{-1}\end{array}$ & water & & & $\begin{array}{l}\text { ether } 2.5 \mathrm{BV} \\
50 \% \text { ethanol } \\
1.5 \mathrm{BV}\end{array}$ & $\begin{array}{l}2 \\
\mathrm{~mL} \cdot \mathrm{min}^{-1}\end{array}$ & $\begin{array}{l}\text { matrine: } \\
67.2 \% \\
\text { oxymatrine: } \\
66.8 \%\end{array}$ & $\begin{array}{l}\text { matrine: } \\
90.3 \% \\
\text { oxymatrine: } \\
86.9 \%\end{array}$ & [6] \\
\hline $\begin{array}{l}\text { Macleaya } \\
\text { cordata } \\
\text { (Willd) R. Br. }\end{array}$ & $\begin{array}{l}\text { chelerythrine } \\
\text { and } \\
\text { sanguinarine }\end{array}$ & $\begin{array}{l}\text { methyl } \\
\text { acrylate-co- } \\
\text { divinylbenzene } \\
\text { macroporous } \\
\text { adsorbents }\end{array}$ & & $0.5 \mathrm{BV} \cdot \mathrm{h}^{-1}$ & water & & & $\begin{array}{l}60 \% \text { ethanol } \\
2 \mathrm{BV} \\
80 \% \text { ethanol } \\
\text { (including } 8 \% \\
\text { acetic acid) } 3 \mathrm{BV}\end{array}$ & $0.5 \mathrm{BV} \cdot \mathrm{h}^{-1}$ & $\begin{array}{l}\text { chelerythrine: } \\
92.8 \% \\
\text { sanguinarine: } \\
96.1 \%\end{array}$ & nearly $90 \%$ & [8] \\
\hline
\end{tabular}

Ps: in the case of no special instructions, the proportions in this table are volume ratios.

\subsubsection{Washing}

There was a washing step after the sample loading in most of the literature. The goal of washing is not only to remove impurities but also to minimize the loss of the target alkaloids. Considering that water is cheap and has a good washing ability for polar substances, such as sugars and salts, researchers chose water to wash impurities in most of the literature. From Table 2, we can see that the volume of water used to wash was generally between 2 - 8 BV [10] [13], and the washing speed was generally between $1-6 \mathrm{BV} \cdot \mathrm{h}^{-1}$ [12] [13]. There is also a study in which an ethanol solution with a low concentration was used for washing, and the concentration of the ethanol solution was below 35\% [14].

\subsubsection{Elution}

The main factors affecting the elution effect include the composition of the eluent, the amount of the eluent, and the flow rate of the eluent. Researchers often used an ethanol solution for elution, and a few used ether [6], a methanol solution [15] [16], an acid solution [8] [17] [18] [19] or a sodium hydroxide solution [20]. According to Table 2, researchers used an ethanol solution of which the concentration was between $50 \%$ and $90 \%$ in most of the literature. However, an 
ethanol solution with a low concentration $(<40 \%)$ was also used as an eluent in a few studies [21] [22] [23]. To separate various alkaloids, using ethanol solutions with different concentrations for multiple elutions can be considered [20] [24] [25]. The desorption of target alkaloids, the desorption of impurities, and the consumption of eluent should be considered in the optimization of the elution volume. In Table 2, the elution volume was generally 4-12 BV [9] [12] [26]. In the optimization of the elution flow rate, the consumption of eluent, time, and column working pressure should be considered. In Table 2, the elution speed was mostly between 1 and $5 \mathrm{BV} \cdot \mathrm{h}^{-1}$, generally not higher than the washing speed [7] [18] [20] [27].

\subsubsection{Refining Results}

In Table 2, the recoveries of alkaloids from macroporous resin column chromatography can often exceed 90\% [11] [28]. This observation indicates that the optimal adsorption and elution conditions can reduce the loss of alkaloids in the chromatography process. The purities of some alkaloids obtained by chromatography reached 95\% [8] [24], and the purities of some alkaloids were less than 5\% [13] [29]. These results show that the Chinese medicine system is complex. High-purity alkaloids may not be obtained by macroporous resin column chromatography alone because the working pressure of macroporous resin chromatography is not high and the processing capacity is also large. Macroporous resin chromatography can be used as a preliminary purification, and then, further purification can be carried out through crystallization and other methods.

\section{Ion Exchange Resin}

\subsection{Properties of Ion Exchange Resins}

Ion exchange resins are organic macromolecular adsorbents with ion exchange groups and a network structure [42]. Ion exchange resins commonly used for alkaloid separation are strongly acidic or weakly acidic cation exchange resins with styrene or acrylic acid macroporous backbone structure, and their properties are listed in Table 3. Some of their photos are shown in Figure 1. Among them, the $001 \times 7$ strong acidic cation exchange resin is most commonly used in alkaloid refining.

\subsection{Ion Exchange Resin Chromatography Separation Process}

The main steps for the purification of alkaloids by ion exchange resins are the same as those of macroporous resins, which also include pretreatment, sampling, washing, elution and regeneration. The sampling, washing, elution steps and purification effects for certain research works are listed in Table 4.

\subsubsection{Sample Loading, Washing and Elution}

Compared with macroporous resins, the characteristics of a sample solution treated by an ion exchange resin include two points. First, the $\mathrm{pH}$ value of the sample solution is mostly less than 3 , which means that the alkaloids are in the 
form of salts when they are loaded. Second, a higher proportion of ethanol is allowed in the sample solvent, which means that the eluate of a macroporous resin may again be refined by the ion exchange resin. In Table 4 , the sample loading speeds are mostly controlled at $2-4 \mathrm{~mL} \cdot \mathrm{min}^{-1}$ or $4-6 \mathrm{BV} \cdot \mathrm{h}^{-1}$. The higher sample loading speed may be related to the larger particle size of ion exchange resins.

After sample loading, the ion exchange resin can be washed with water first. The washing speeds listed in Table 4 shall not be lower than the sample loading speeds.

Table 3. Performance parameters of ion exchange resins.

\begin{tabular}{|c|c|c|c|c|c|c|c|}
\hline $\begin{array}{l}\text { Resin } \\
\text { model }\end{array}$ & $\begin{array}{l}\text { Maternal } \\
\text { model }\end{array}$ & Structure & $\begin{array}{l}\text { Functional } \\
\text { group }\end{array}$ & Appearance & $\begin{array}{c}\text { Exchange } \\
\text { capacity } /\left(\mathrm{mmol}^{-1} \mathrm{~g}^{-1}\right)\end{array}$ & $\begin{array}{l}\text { Particle size } \\
\text { range/mm }\end{array}$ & Reference \\
\hline $001 \times 7$ & styrene & gel & $-\mathrm{SO}_{3} \mathrm{H}$ & $\begin{array}{l}\text { brown to tan } \\
\text { globular granules }\end{array}$ & $\geq 4.5$ & $0.40-0.70$ & [43] [44] \\
\hline $001 \times 2.5$ & styrene & gel & $-\mathrm{SO}_{3} \mathrm{H}$ & $\begin{array}{l}\text { brown-yellow } \\
\text { globular granules }\end{array}$ & $\geq 4.30$ & $0.400-1.250$ & [45] \\
\hline D-151 & acrylic acid & macropore & $-\mathrm{COOH}$ & $\begin{array}{c}\text { milky opaque } \\
\text { globular particles }\end{array}$ & $\geq 9.50$ & $0.315-1.25$ & [46] \\
\hline D-152 & acrylic acid & macropore & $-\mathrm{COOH}$ & $\begin{array}{c}\text { milky opaque } \\
\text { globular particles }\end{array}$ & $\geq 9.00$ & $0.315-1.25$ & [46] [47] \\
\hline
\end{tabular}

Table 4. Study on the separation of alkaloids by ion exchange resin chromatography.

\begin{tabular}{|c|c|c|c|c|c|c|c|c|c|c|c|}
\hline \multirow[b]{2}{*}{$\begin{array}{l}\text { Chinese } \\
\text { medicines }\end{array}$} & \multirow[b]{2}{*}{ Alkaloids } & \multirow[b]{2}{*}{$\begin{array}{l}\text { Resin } \\
\text { Type }\end{array}$} & \multicolumn{2}{|c|}{ Loading Process } & \multicolumn{2}{|c|}{ Washing Process } & \multicolumn{3}{|l|}{ Elution Process } & \multirow{2}{*}{\multicolumn{2}{|c|}{ RecoveryReference }} \\
\hline & & & $\begin{array}{l}\mathrm{pH} \text { Value } \\
\text { of Sample } \\
\text { Solution }\end{array}$ & $\begin{array}{l}\text { Sample } \\
\text { Flow Rate }\end{array}$ & Detergen & Volume of & $\begin{array}{l}\text { Eluent } \\
\text { Composition }\end{array}$ & $\begin{array}{l}\text { Elution } \\
\text { Flow Rate }\end{array}$ & $\begin{array}{l}\text { Volume } \\
\text { of Eluate }\end{array}$ & & \\
\hline $\begin{array}{l}\text { Cynoglossum } \\
\text { amabile }\end{array}$ & $\begin{array}{l}\text { total } \\
\text { alkaloids }\end{array}$ & $001 \times 7$ & 2 & $6 \mathrm{BV} \cdot \mathrm{h}^{-1}$ & water & $5 \mathrm{BV}$ & $\begin{array}{l}1 \mathrm{~mol} \cdot \mathrm{L}^{-1} \\
\text { Sodium chloride } \\
\text { solution }\end{array}$ & $6 \mathrm{BV} \cdot \mathrm{h}^{-1}$ & $26 \mathrm{BV}$ & & {$[50]$} \\
\hline $\begin{array}{l}\text { Corydalis } \\
\text { hendersonii }\end{array}$ & $\begin{array}{l}\text { total } \\
\text { alkaloids }\end{array}$ & $001 \times 7$ & & & water & $6 \mathrm{BV}$ & $\begin{array}{l}70 \% \text { ethanol - 5\% } \\
\text { ammonium } \\
\text { hydroxide }\end{array}$ & & $6 \mathrm{BV}$ & $>45 \%$ & {$[51]$} \\
\hline Motherwort & $\begin{array}{l}\text { total } \\
\text { alkaloids }\end{array}$ & $001 \times 7$ & 2 & & water & & $\begin{array}{l}5 \% \text { ammonium } \\
\text { hydroxide } \\
70 \% \text { ethanol } \\
5 \% \text { ammonium } \\
\text { hydroxide }\end{array}$ & & & & {$[49]$} \\
\hline $\begin{array}{l}\text { Uncaria } \\
\text { rhynchophylla }\end{array}$ & $\begin{array}{l}\text { total } \\
\text { a alkaloids }\end{array}$ & $001 \times 7$ & & $6 \mathrm{BV} \cdot \mathrm{h}^{-1}$ & water & & $\begin{array}{l}5 \% \text { Sodium } \\
\text { chloride solution } \\
-50 \% \text { ethanol }\end{array}$ & $8 \mathrm{BV} \cdot \mathrm{h}^{-1}$ & $10 \mathrm{BV}$ & $47.60 \% 89.9 \%$ & {$[48]$} \\
\hline Sini powder & $\begin{array}{l}\text { total } \\
\text { alkaloids }\end{array}$ & $001 \times 7$ & 2 & & & & $\begin{array}{l}4 \% \text { ammonium } \\
\text { hydroxide - } \\
\text { ethanol }\end{array}$ & & $40 \mathrm{~mL}$ & $0.373 \%$ & {$[52]$} \\
\hline $\begin{array}{l}\text { Ephedra and } \\
\text { Hindu datura } \\
\text { flower }\end{array}$ & $\begin{array}{l}\text { total } \\
\text { alkaloids }\end{array}$ & D-151 & 11 & $\begin{array}{l}4.0 \\
\mathrm{~mL} \cdot \mathrm{min}^{-1}\end{array}$ & water & $300 \mathrm{~mL}$ & $\begin{array}{l}0.08 \mathrm{~mol} \cdot \mathrm{L}^{-1} \\
\text { hydrochloric } \\
\text { acid }\end{array}$ & $\begin{array}{l}4.0 \\
\mathrm{~mL} \cdot \mathrm{min}^{-1}\end{array}$ & $750 \mathrm{~mL}$ & $76.14 \%$ & {$[53]$} \\
\hline
\end{tabular}


It can be seen from Table 4 that the eluent for refining alkaloids by ion exchange resin chromatography is usually an alcohol solution, ammonium hydroxide, sodium chloride solution, acid added solution, etc. The concentration of ethanol solution is generally more than $50 \%$. A comparison of macroporous resins and ion exchange resins on the adsorption and desorption of alkaloids are shown in Figure 2.

Wang et al. [48] used the $001 \times 7$ ion exchange resin to separate and purify the total alkaloids of Uncaria and found that the $50 \%$ ethanol solution of $5 \%$ sodium chloride had a high elution rate for the total alkaloids. Peng et al. [49] found that $5 \%$ ammonia and $70 \%$ ethanol could wash out part of Leonurus alkaloids. In the literature, the range of elution velocities is $6-8 \mathrm{BV} \cdot \mathrm{h}^{-1}$. In the literature, there are examples of not only a fixed elution volume but also the determination of the high performance liquid chromatography (HPLC) [50] and precipitation reactions [49].

\subsubsection{Refining Results}

From Table 4, it can be seen that the purity of alkaloids separated by ion exchange resin chromatography is between $0.3 \%$ and $78 \%$, and the recovery of alkaloids is between $76 \%$ and $92 \%$. Compared with macroporous resins, the purity of total alkaloids from ion exchange resins is not high.

\section{Silica Gel}

\subsection{Properties of Silica Gel for Column Chromatography}

The silica gel for column chromatography is generally a transparent or milky-white

(a) Macroporous resins
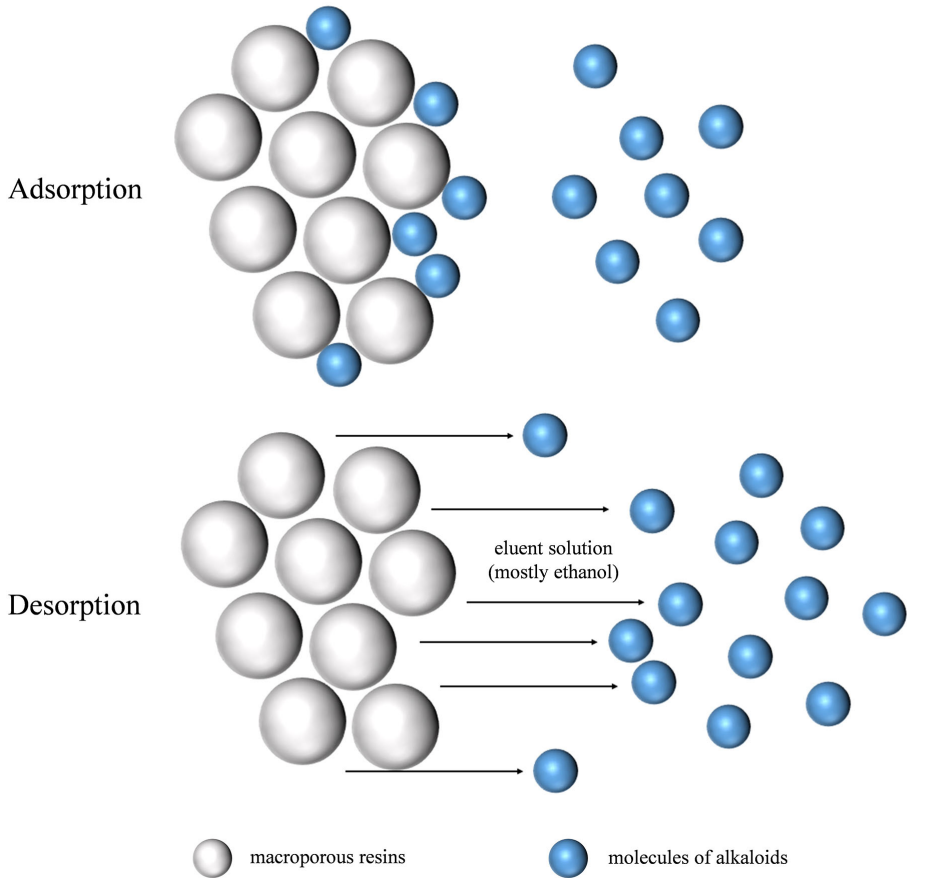

(b) Ion exchange resins
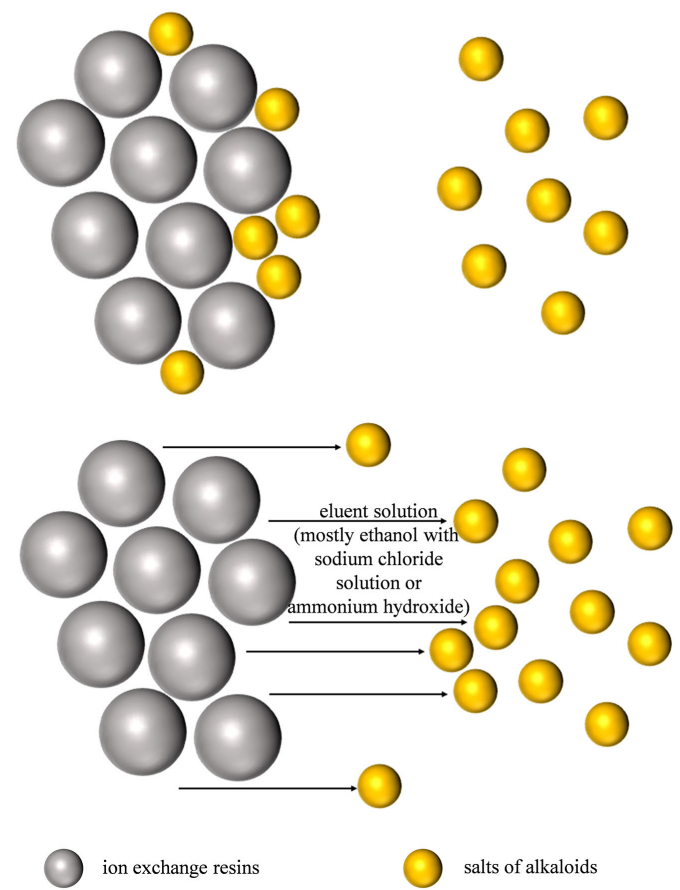

Figure 2. Comparison of macroporous resins and ion exchange resins on the adsorption and desorption of alkaloids. 
granular solid with a microporous structure, which has the advantages of a high adsorption performance, stable physical and chemical properties, high mechanical strength and renewable use. In general, the van der Waals force is used to adsorb organic molecules from the solution, and the differences in the adsorption capacity for different molecules are used for separation from the silica gel during elution. At present, there are many reports about silica gel being used to refine the alkaloids of Chinese medicines, as seen in Table 5. It can be seen from the table that most silica gel used for column chromatography is $200-300$ mesh, and its particle size range is $45-75 \mu \mathrm{m}$. The smaller particle size is beneficial to increase the specific surface area for adsorption and separation effects, but it will also increase the pressure in the chromatography process.

\subsection{Separation Technology of Silica Gel Chromatography}

\subsubsection{Loading and Elution}

When silica gel is used as an adsorbent, in addition to the wet method, the dry method is also often used. The operation of wet sampling is more convenient, but dry sampling can solve the problem of low solubility of the components to be separated in the sample solution.

For a positive silica gel, the eluant includes chloroform methanol [54] [55], methanol water [56], methanol [57] [58], etc., and sometimes ammonium hydroxide [59] [60] are added to adjust the $\mathrm{pH}$ value of the eluant. For a reversed phase silica gel, the eluant is generally an organic solvent water solution. Compared with macroporous resins and ion exchange resins, gradient elution is commonly used when silica gel is used as the adsorbent. Gradient elution is more complex than isoelution, but it is beneficial to obtain high-purity alkaloids.

The amount of eluent and the elution time should be considered when choosing the elution flow rate. The elution flow rate is usually $0.5-1 \mathrm{BV} \cdot \mathrm{h}^{-1}$, which is substantially slower than that of macroporous adsorption resins and ion exchange resins. The main reason is that the particle size of silica gel is obviously smaller than that of the commonly used macroporous adsorption resin or ion exchange resin, and the operating pressure will be high when the flow rate is large.

\subsubsection{Refining Results}

It can be seen from Table 5 that the purity of the products obtained from silica gel separation of alkaloids is mostly over $90 \%$, sometimes even close to $100 \%$. Compared with ion exchange resins and macroporous resins, the purity of the product is high. The overall recovery in Table 5 is not high, which may be due to the sacrifice of the recovery to obtain high-purity target alkaloids. If the purity of the alkaloids is required to be high, macroporous adsorption resins or ion exchange resins can be used for a crude separation, and then, silica gel can be used for refining.

\section{Modeling Method}

Modeling is important for the chromatography process optimization. In general, 
Y. Q. He et al.

Table 5. Study on the separation of alkaloids by silica gel chromatography.

\begin{tabular}{|c|c|c|c|c|c|c|c|c|}
\hline \multirow{3}{*}{$\begin{array}{l}\text { Chinese } \\
\text { medicines }\end{array}$} & \multirow{3}{*}{ Alkaloids } & \multicolumn{2}{|l|}{ Adsorbent } & \multicolumn{2}{|c|}{ Elution Process } & \multirow{3}{*}{ Purity } & \multirow{3}{*}{ Recovery } & \multirow{3}{*}{ Reference } \\
\hline & & \multirow{2}{*}{ Type } & \multicolumn{2}{|c|}{ Mesh/ParticleEluent } & \multirow{2}{*}{$\begin{array}{l}\text { Elution } \\
\text { Method }\end{array}$} & & & \\
\hline & & & Size & Composition & & & & \\
\hline $\begin{array}{l}\text { Lindera } \\
\text { aggregata }\end{array}$ & $\begin{array}{l}\text { several fractions of } \\
\text { aconite alkaloids }\end{array}$ & $\begin{array}{l}\text { C18-reversed } \\
\text { silica gel }\end{array}$ & & $\begin{array}{l}\text { methanol - } \\
\text { water }\end{array}$ & $\begin{array}{l}\text { gradient } \\
\text { elution }\end{array}$ & & & {$[56]$} \\
\hline $\begin{array}{l}\text { Clausena } \\
\text { anisum-olens }\end{array}$ & $\begin{array}{l}8 \text { fractions of aconite } \\
\text { alkaloids }\end{array}$ & silica gel & & $\begin{array}{l}\text { petroleum } \\
\text { ether - ethyl } \\
\text { acetate } \\
\text { ethyl acetate } \\
\text { ethyl acetate - } \\
\text { methanol } \\
\text { methanol }\end{array}$ & $\begin{array}{l}\text { gradient } \\
\text { elution }\end{array}$ & & & [61] \\
\hline $\begin{array}{l}\text { Angelica } \\
\text { dahurica }\end{array}$ & $\begin{array}{l}20 \text { fractions of } \\
\text { aconite alkaloids }\end{array}$ & $\begin{array}{l}\text { RP-C18-reversed } \\
\text { silica gel }\end{array}$ & & $\begin{array}{l}\text { methanol - } \\
\text { water }\end{array}$ & $\begin{array}{l}\text { gradient } \\
\text { elution }\end{array}$ & & & [58] \\
\hline $\begin{array}{l}\text { Rauvolfia } \\
\text { yunnanensis }\end{array}$ & $\begin{array}{l}2 \text { fractions of aconite } \\
\text { alkaloids }\end{array}$ & silica gel & & $\begin{array}{l}\text { chloroform - } \\
\text { methanol }\end{array}$ & $\begin{array}{l}\text { gradient } \\
\text { elution }\end{array}$ & & & {$[54]$} \\
\hline $\begin{array}{l}\text { Herba } \\
\text { Aconiti }\end{array}$ & $\begin{array}{l}\text { heteratisine, } \\
\text { hordenine, } \\
\text { talatisamine }\end{array}$ & silica gel & & $\begin{array}{l}\text { cyclohexane - } \\
\text { acetone }\end{array}$ & $\begin{array}{l}\text {-gradient } \\
\text { elution }\end{array}$ & all $>98 \%$ & & {$[58]$} \\
\hline $\begin{array}{l}\text { Semen } \\
\text { holarrhenae }\end{array}$ & $\begin{array}{l}\text { total alkaloids } \\
\text { (containing three } \\
\text { alkaloid monomers) }\end{array}$ & silica gel & $\begin{array}{l}200-300 \\
\text { mesh }\end{array}$ & $\begin{array}{l}\text { chloroform - } \\
\text { methanol }\end{array}$ & $\begin{array}{l}\text { gradient } \\
\text { elution }\end{array}$ & $\begin{array}{l}\text { chemical compound } \\
\text { 1: } 89.23 \% \text {, chemical } \\
\text { compound } 2: 94.89 \% \text {, } \\
\text { chemical compound } \\
\text { 3: } 62.64 \%\end{array}$ & & [55] \\
\hline & $\begin{array}{l}4 \text { fractions of } \\
\text { aconite alkaloids }\end{array}$ & silica gel & $\begin{array}{l}200-300 \\
\text { mesh }\end{array}$ & $\begin{array}{l}\text { petroleum } \\
\text { ether - ace- } \\
\text { tone }\end{array}$ & $\begin{array}{l}\text { gradient } \\
\text { elution }\end{array}$ & & & \\
\hline Fritillary & suchengbeisine & silica gel & $\begin{array}{l}200-300 \\
\text { mesh }\end{array}$ & $\begin{array}{l}\text { chloroform - } \\
\text { methanol }\end{array}$ & $\begin{array}{l}\text { gradient } \\
\text { elution }\end{array}$ & & & [62] \\
\hline & verticinone-N-oxide & silica gel & $\begin{array}{l}200-300 \\
\text { mesh }\end{array}$ & $\begin{array}{l}\text { chloroform - } \\
\text { methanol }\end{array}$ & $\begin{array}{l}\text { gradient } \\
\text { elution }\end{array}$ & & & \\
\hline $\begin{array}{l}\text { Corydalis } \\
\text { saxicola }\end{array}$ & total alkaloids & silica gel & $\begin{array}{l}200-300 \\
\text { mesh }\end{array}$ & $\begin{array}{l}\text { chloroform - } \\
\text { methanol }\end{array}$ & $\begin{array}{l}\text { gradient } \\
\text { elution }\end{array}$ & & & [63] \\
\hline $\begin{array}{l}\text { Aconitum } \\
\text { taipeicum }\end{array}$ & total alkaloids & silica gel & & $\begin{array}{l}\text { chloroform - } \\
\text { methanol }\end{array}$ & $\begin{array}{l}\text { gradient } \\
\text { elution }\end{array}$ & & & {$[64]$} \\
\hline $\begin{array}{l}\text { Semen } \\
\text { plantaginis }\end{array}$ & $\begin{array}{l}7 \text { fractions of aconite } \\
\text { alkaloids }\end{array}$ & silica gel & & $\begin{array}{l}\text { chloroform - } \\
\text { methanol - } \\
\text { ammonium } \\
\text { hydroxide }\end{array}$ & $\begin{array}{l}\text { isocratic } \\
\text { elution }\end{array}$ & & & [59] \\
\hline $\begin{array}{l}\text { Catharanthus } \\
\text { roseus }\end{array}$ & $\begin{array}{l}\text { vincristine, } \\
\text { vincaleukoblastinum }\end{array}$ & silica gel & & $\begin{array}{l}\text { carrene - } \\
\text { methanol }\end{array}$ & $\begin{array}{l}\text { gradient } \\
\text { elution }\end{array}$ & $\begin{array}{l}\text { vincristine: } 97.26 \% \text {, } \\
\text { vincaleukoblastinum: } \\
94.18 \%\end{array}$ & $\begin{array}{l}\text { vincristine: } 61.12 \% \text {, } \\
\text { vincaleukoblastinum: } \\
58.50 \%\end{array}$ & [65] \\
\hline $\begin{array}{l}\text { Sophora } \\
\text { alopecuroide }\end{array}$ & $\begin{array}{l}\text { N-oxysophocarpine, } \\
\text { oxymatrine }\end{array}$ & silica gel & $\begin{array}{l}200-300 \\
\text { mesh }\end{array}$ & $\begin{array}{l}\text { chloroform - } \\
\text { methanol - } \\
\text { ammonium } \\
\text { hydroxide }\end{array}$ & $\begin{array}{l}\text { isocratic } \\
\text { elution }\end{array}$ & $>99 \%$ & & [60] \\
\hline & sophoridine & silica gel & $\begin{array}{l}200-300 \\
\text { mesh }\end{array}$ & $\begin{array}{l}\text { Acetone - } \\
\text { methanol }\end{array}$ & $\begin{array}{l}\text { isocratic } \\
\text { elution }\end{array}$ & $95.80 \%$ & & \\
\hline $\begin{array}{l}\text { Sophora } \\
\text { alopecuroide }\end{array}$ & matrine, oxymatrine & silica gel & $\begin{array}{l}300-400 \\
\text { mesh }\end{array}$ & $\begin{array}{l}\text { chloroform, } \\
\text { chloroform - } \\
\text { methanol }\end{array}$ & $\begin{array}{l}\text { isocratic } \\
\text { elution }\end{array}$ & $\begin{array}{l}\text { matrine: }>95 \% \text {, } \\
\text { oxymatrine: }>95 \%\end{array}$ & $\begin{array}{l}\text { matrine: } 22.2 \% \text {, } \\
\text { oxymatrine: } 42.6 \%\end{array}$ & [66] \\
\hline
\end{tabular}


it is possible to obtain the global optimal conditions only by establishing the model first.

\subsection{Modeling Based on Statistics}

Dr. Yu suggested adopting a design of experiments in research on pharmaceutical processes [67]. Some researchers adopt the Taguchi design to study the technological parameters of column chromatography [9] [12] [14] [35]. This design requires a few experiments, but the obtained data can only be modeled by linear equations. The Box-Behnken design [20], by contrast, enables researchers to model second-order polynomials with quadratic terms and interaction terms, although the design requires more experiments. The second-order polynomials modeled are beneficial to obtain the optimum conditions in the research scope after optimization. The model form is generally as shown in Formula (1).

$$
Y=a_{0}+\sum_{i=1}^{m} a_{i} X_{i}+\sum_{i=1}^{m} a_{i i} X_{i}^{2}+\sum_{i=1}^{m-1} \sum_{j=i+1}^{m} a_{i j} X_{i} X_{j}
$$

where $Y$ is the response variable; $a_{0}$ is a constant; $a_{j} a_{i p}$ and $a_{i j}$ are the linear, quadratic, and cross-product coefficients, respectively; $X_{i}$ and $X_{j}$ are different parameters; and $\mathrm{m}$ is the number of parameters.

\subsection{Thermodynamic Model of Static Adsorption}

In static adsorption, the adsorption capacity of a macroporous resin for alkaloids can be evaluated by adsorption isotherms. There may be many forms of adsorption isotherms. Certain examples are listed in Table 6. The Langmuir and Freundlich models are widely used in the study of alkaloid chromatography [6] [7] [18] [27] [39]. Because of the complexity of the adsorption principle, the above two models are often used by researchers at the same time to compare and choose the better one according to the determination coefficient $\left(R^{2}\right)$ [6] [18] [39].

\subsection{Kinetic Model of Static Adsorption}

The static adsorption rate is an important index when optimizing the resin for refining alkaloids. The results can be fitted by using a variety of models, as seen in Table 7.

The pseudo-first-order and pseudo-second-order kinetic models are the most commonly used empirical models for alkaloid adsorption [73] [74] [75]. The pseudo-first-order kinetic model is more accurate in fitting the initial stage of adsorption when the initial concentration of adsorbate is high, while the pseudo-second-order kinetic model is suitable for fitting the subsequent stage of adsorption when the initial concentration is low, and the pseudo-nth-order model dynamics is the generalization result of these two models. The mixed order model combines the pseudo-first-order kinetic model and the pseudo-second-order kinetic model, so it can be used to fit the whole adsorption process of any initial concentration. 
Table 6. Common adsorption isotherm equations.

\begin{tabular}{|c|c|c|c|c|}
\hline Name & Form & Meaning of Parameter & Applicability & Reference \\
\hline Langmuir & $q_{e}=\frac{q_{m} C_{e}}{K_{L}+C_{e}}$ & $\begin{array}{l}q_{e}: \text { the adsorption capacity at adsorption equilibrium } \\
(\mathrm{mg} / \mathrm{g}-\text { resin) } \\
q_{m}: \text { the theoretical maximum adsorption capacity } \\
(\mathrm{mg} / \mathrm{g} \text {-resin) } \\
K_{L}: \text { the Langmuir constant } \\
C_{e}: \text { the equilibrium concentration in liquid phase }\end{array}$ & $\begin{array}{l}\text { Monolayer adsorption on } \\
\text { uniform surface }\end{array}$ & [18] \\
\hline Freundlich & $q_{e}=K_{F} C_{e}^{1 / n}$ & $\begin{array}{l}K_{F} \text { : the Freundlich constant } \\
1 / n \text { : an empirical constant }\end{array}$ & $\begin{array}{l}\text { Monolayer adsorption on a } \\
\text { heterogeneous surface }\end{array}$ & [39] \\
\hline Henry & $q_{e}=K_{H} C_{e}$ & $K_{H}$ : the Henry constant & $\begin{array}{l}\text { The amount of adsorption accounts } \\
\text { for less than } 10 \% \text { of the amount of } \\
\text { adsorption forming the monolayer }\end{array}$ & [68] \\
\hline Redlich-Peterson & $q_{e}=\frac{K_{R} C_{e}}{1+a_{R} C_{e}^{g}}$ & $\begin{array}{l}K_{R} \text { : the Redlich-Peterson constant } \\
a_{R}: \text { an empirical constant } \\
g \text { : an empirical constant that is between } 0 \text { and } 1\end{array}$ & Monolayer adsorption & [69] \\
\hline
\end{tabular}

Table 7. Common static adsorption kinetic equations.

\begin{tabular}{lll}
\hline Name & Form & Meaning of Parameter
\end{tabular}

\section{Conclusions}

In conclusion, there are many studies on the purification of alkaloids by chromatography. The most commonly used adsorbents are macroporous adsorption resins, ion exchange resins and silica gel. In the separation and purification of alkaloids, a nonpolar macroporous resin is often used. The purity of alkaloids from an ion exchange resin and macroporous resin is not high, but the purity of alkaloids from silica gel refining is high. Compared with silica gel, macroporous resins and ion exchange resins are cheaper and have a lower operating pressure, so they are more suitable for the preliminary separation of alkaloids.

The authors think that future research can be carried out in the following directions:

Firstly, the modeling method of the column chromatography process needs to 
be further studied. The dynamic adsorption process is usually described by the general rate model [76]. Xu et al. [77] used the model to simulate the chromatography of a simulation system containing Puerarin and Daidzein, and the results were in good agreement with the experimental values. It is difficult to describe the phenomenon of competitive adsorption because of the complexity of the components in Chinese medicine extract. To date, there has been no research report related to the general rate model of alkaloid chromatography. Therefore, it is still necessary to develop effective modeling methods to describe the chromatography process of Chinese medicine extracts.

Secondly, stricter quality control methods should be established. There are differences in the content of components in different batches of Chinese medicine extract solution, which affect the effect of chromatography. However, there is no research focus on the influence of the quality change in the sample solution on the chromatography effect so far. To control the consistency between different batches of alkaloids, it is suggested to set the quality standard of the sample solution. Pan et al. [78] established a quantitative model of process parameters, raw material properties and evaluation indexes of column chromatography eluent and then calculated the quality standards of raw materials according to the requirements of the evaluation indexes. This idea can be used for reference to establish the quality standard of a sample solution for alkaloid column chromatography.

Thirdly, online detection of chromatography processes should be strengthened. At present, in academia, spectral technologies combined with multivariate statistical methods are often used to detect the content of indicators/major components in Chinese medicines or to detect the process trajectory [79] [80] [81]. This approach has the advantage of real-time online quantitative detection. However, it has not been reported that it can be used in the chromatography of alkaloids, so it needs further development.

\section{Acknowledgements}

Conceptualization, H.Q. and X.G.; Formal analysis, Y.H. and Z.C.; Funding acquisition, H.Q., X.G., Y.H. and Z.C.; Investigation, Y.H. and Z.C.; Project administration, H.Q.; Resources, H.Q. and X.G.; Supervision, H.Q. and X.G.; Writing-original draft, Y.H. and Z.C.; Writing-review and editing, H.Q. and X.G.

\section{Funding}

This work was supported by the National S\&T Major Project of China (2018 ZX09201011-002), the National Project for Standardization of Chinese Materia Medica (ZYBZH-C-YN-58), and Student Research Training Program of College of Pharmaceutical Sciences of Zhejiang University (Y202004167). Funders had no role in study design, collection, analysis and interpretation of data and in writing the manuscript. 


\section{Conflicts of Interest}

The authors declare no conflicts of interest regarding the publication of this paper.

\section{References}

[1] Liu, Y., Chen, W.H., Kang, D., Li, W.L. and Li, Z. (2020) Research Progress on Macroporous Resin Application in Enriching and Separating Alkaloids. Chinese Traditional and Herbal Drugs, 51, 1650-1659.

[2] Liu, Y.T., et al. (2018) Chemical Constituents and Antioxidant, Anti-Inflammatory and Anti-Tumor Activities of Melilotus officinalis (Linn.) Pall. Molecules, 23, 271. https://doi.org/10.3390/molecules23020271

[3] Farag, M., Abdel-Mageed, W.M., Basudan, O. and El-Gamal, A. (2018) Persicaline, a New Antioxidant Sulphur-Containing Imidazoline Alkaloid from Salvadora persica Roots. Molecules, 23, 483. https://doi.org/10.3390/molecules23020483

[4] Xin, L., et al. (2014) Research on Hypnotic and Anticonvulsant Activities of Total Alkaloids in Leaves of Eucommia ulmoides. Chinese Herbal Medicines (CHM), 6, 131-135. https://doi.org/10.1016/S1674-6384(14)60020-4

[5] Huang, Y.Y., et al. (2016) Separation and Purification of Indigotin and Indirubin from Folium isatidis Extracts Using a Fast and Efficient Macroporous Resin Column Followed Reversed Phase Flash Chromatography. Journal of the Taiwan Institute of Chemical Engineers, 67, 61-68. https://doi.org/10.1016/j.jtice.2016.07.030

[6] Chen, H.H., Luo, S.J., Zheng, X.K. and Fan, H.J. (2016) Separation of Matrine and Oxymatrine from Sophora flavescens Extract through Cation Exchange Resin Coupled with Macroporous Absorption Resin. Polish Journal of Chemical Technology, 18, 31-39. https://doi.org/10.1515/pjct-2016-0026

[7] Yang, J., Zhang, L.Y., Zhu, G.H. and Li, L. (2014) Separation and Enrichment of Major Quinolizidine Type Alkaloids from Sophora alopecuroides Using Macroporous Resins. Journal of Chromatography B, 945-946, 17-22. https://doi.org/10.1016/j.jchromb.2013.11.023

[8] Pi, G., et al. (2008) Separation of Sanguinarine and Chelerythrine in Macleaya cordata (Willd) R. Br. Based on Methyl Acrylate-Co-Divinylbenzene Macroporous Adsorbents. Journal of Chromatography A, 1192, 17-24. https://doi.org/10.1016/j.chroma.2008.03.039

[9] Wang, X., Leng, X. and Guo, H. (2015) Study on the Total Alkaloids Separation and Purification from Sophora alopecuroides L. Using Macroporous Resin. Northwest Pharmaceutical Journal, 30, 674-679.

[10] Li, X.J., Li, Y., Cheng, X.M., Wang, Z.T. and Wang, C.H. (2013) Separation and Purification of Total Alkaloids from Colchicum autumnale L.with Macroporous Adsorption Resin. Chinese Traditional Patent Medicine, 35, 1667-1671.

[11] Guo, H., Leng, X., Chen, H. and Hao, C. (2015) Study on the Separation and Purification of Total Alkaloids from the Seeds of Kudouzi. Western Journal of Traditional Chinese Medicine, 28, 49-52.

[12] Xiao, Z., et al. (2019) Study on Separation and Purification Process of Total Alkaloids from Corydalis by Macroporous Adsorption Resin HPD-100. China Journal of Traditional Chinese Medicine and Pharmacy, 34, 2754-2757.

[13] Li, Y., et al. (2015) Separation and Purification of Total Alkaloids from Hyoscyami Semen by Macroporous Resin. Chinese Traditional Patent Medicine, 37, 89-94. 
[14] Zhang, Y.Y., Xuan, G.D. and Li, L.L. (2010) Separation and Purification of Total Alkaloids from the Peels of Carya cathayensis Sarg. by Macroporous Adsorption Resin. Journal of Zhejiang University (Science Edition), 37, 463-466.

[15] Chen, X.P., Yang, P. and Zhang, Y.D. (2009) Studies on Separation and Purification of Alkaloid from Lotus Leaves and Inhibition Effects of Extracts on Lipase Activity. Research of Agricultural Modernization, 30, 748-751+760.

[16] Wang, P., Luo, X.B., Chen, B. and Yao, S.Z. (2006) Isolation and Purification of Aporphine Alkaloids with Macroporous Adsorption Resin. Chinese Traditional and Herbal Drugs, 37, 355-358.

[17] Liao, X.X., Zha, L.H., Liu, X., Ma, G.H. and Su, Z.G. (2004) Process Optimization on Separation of Alkaloids from Ephedra with Chromatography. Natural Product Research and Development, 16, 281-285.

[18] Liu, J.J., et al. (2014) Enrichment and Purification of Six Aconitum Alkaloids from Aconiti kusnezoffii Radix by Macroporous Resins and Quantification by HPLC-MS. Journal of Chromatography. B, Analytical Technologies in the Biomedical and Life Sciences, 960, 174-181. https://doi.org/10.1016/j.jchromb.2014.04.034

[19] Qin, X.G. and Chen, J.C. (2010) Study on Adsorption and Separation of Alkaloids in Sophora flavescens Ait.with X-5 Macroporous Resin. Chinese Journal of Experimental Traditional Medical Formulae, 16, 29-31.

[20] Lu, Y.M. and Cui, B. (2019) Extraction and Purification of Capsaicin from Capsicum Oleoresin Using a Combination of Tunable Aqueous Polymer-Phase Impregnated Resin (TAPPIR) Extraction and Chromatography Technology. Molecules, 24, 3956. https://doi.org/10.3390/molecules24213956

[21] Xu, X.H., Zhang, T.-J., Liao, M.-L., Liu, K.-Y. and Wu, Y.-J. (2007) Separation and Purification of Total Alkaloid from Rhizoma coptidis by Macroreticular Adsorbent Resin. Chinese Traditional and Herbal Drugs, 38, 1167-1170.

[22] Li, K.K., et al. (2016) Preparative Separation of Gallocatechin Gallate from Camellia ptilophylla Using Macroporous Resins Followed by Sephadex LH-20 Column Chromatography. Journal of Chromatography. B, Analytical Technologies in the Biomedical and Life Sciences, 1011, 6-13. https://doi.org/10.1016/j.jchromb.2015.12.039

[23] Zou, D.L., et al. (2018) PH-Zone-Refining Counter-Current Chromatography with a Hydrophilic Organic/Salt-Containing Two-Phase Solvent System for Preparative Separation of Polar Alkaloids from Natural Products. Journal of Chromatography $A, 1553,1-6$. https://doi.org/10.1016/j.chroma.2018.04.007

[24] Zhao, Q.C., Guo, T., Zhang, P., Zhang, Y.X. and Zhang, L. P. (2006) Study on Separation and Isolation of Total Alkaloids from Gelsemium elegans Benth.by Macroporous Resin. China Pharmacy, No. 13, 969-971.

[25] Jiang, B.Y., et al. (2012) Diterpenoid Alkaloids from the Lateral Root of Aconitum carmichaelii. Journal of Natural Products, 75, 1145-1159. https://doi.org/10.1021/np300225t

[26] Wang, H.S., Wu, S.S., Wang, Y.H. and Qiu, S.P. (2015) Separation and Purification of Total Alkaloids from Gelsemium elegans Benth. Root of Fujian. Strait Pharmaceutical Journal, 27, 46-49.

[27] Wang, D.D., et al. (2014) Optimization of Extraction and Enrichment of Steroidal Alkaloids from Bulbs of Cultivated Fritillaria cirrhosa. BioMed Research International, 2014, Article ID: 258402. https://doi.org/10.1155/2014/258402

[28] Liu, S., Lei, P., Li, X.Z. and Chen, Y.H. (2007) Separation and Purification Processes of Alkaloids from Lotus Plumule with Macroporous Adsorption Resin. China Jour- 
nal of Chinese Materia Medica, 32, 912-915.

[29] Zhang, H.C., Liang, H., Kuang, P.Q., Yuan, Q.P. and Wang, Y. (2012) Simultaneously Preparative Purification of Huperzine A and Huperzine B from Huperzia serrata by Macroporous Resin and Preparative High Performance Liquid Chromatography. Journal of Chromatography. B, Analytical Technologies in the Biomedical and Life Sciences, 904, 65-72. https://doi.org/10.1016/j.jchromb.2012.07.019

[30] Li, C.S., Du, A.L., Li, X. and Du, A.Q. (2013) Separation and Purification of Matrine and Oxymatrine with H103 Macroporous Resin. Fine Chemicals, 30, 293-298.

[31] Lu, S.H. and Long, S.J. (2013) Separation and Purification of Total Alkaloids from Zanthoxylum nitidum (Roxb.) DC.With D-101 Macroporous Resin. Northwest Pharmaceutical Journal, 28, 7-9.

[32] Liu, D.Y., Wang, Y. and Jiang, J.Q. (2012) Isolation and Purification of Flavonoids and Alkaloids from the Leaf of Nelumbo nucifera Gaertn by Macroporous Adsorption Resin. Northwest Pharmaceutical Journal, 27, 511-514.

[33] Huang, J.H., Zeng, J.G., Guo, Y.G., Tan, M.L. and Duan, X.P. (2011) Separation and Purification of Protopine Alkaloids from Macleaya microcarpa (Maxim.) Fedde Fruit by Macroreticular Resin. Central South Pharmacy, 9, 897-901.

[34] Xiao, W.J., Hu, X.W., Hu, Y.L., Xiao, L.Z. and Gong, Z.H. (2007) Technology Study on Column Separation and Purification for Alkaloid in Lotus Leaves. Food Science, 28, 120-124.

[35] Zhang, P., et al. (2007) Separation and Purification of Total Alkaloids from Fritillaria hupehensis Hsiao et K.C.HSia. With Macroporous Adsorption Resin. Chinese Traditional Patent Medicine, No. 1, 51-54.

[36] Yu, J.S. and Yu, J.P. (2007) Study on Separation and Purification of Total Alkaloids from Macleaya cordata. Journal of Chinese Medicinal Materials, 30, 1008-1012.

[37] Zhang, Y.P., et al. (2020) Optimization of the Extraction and Purification of Corydalis yanhusuo W.T. Wang Based on the Q-Marker Uniform Design Method. BMC Chemistry, 14, 9.

[38] Turghun, C., Bakri, M., Abudulla, R., Sun, G. and Aisa, H.A. (2018) UHPLC-MS ${ }^{\text {- }}$ Assisted Characterization of Bioactive Alkaloids Extracted from Nitraria sibirica Leaves and Enriched Using Response Surface Method and Adsorption on Macroporous Resin. Industrial Crops and Products, 125, 529-536. https://doi.org/10.1016/j.indcrop.2018.09.038

[39] Pan, J.L., et al. (2017) Enrichment of Chelidonine from Chelidonium majus L. Using Macroporous Resin and Its Antifungal Activity. Journal of Chromatography. $B$, Analytical Technologies in the Biomedical and Life Sciences, 1070, 7-14. https://doi.org/10.1016/j.jchromb.2017.10.029

[40] Xiao, J., et al. (2019) High Performance Liquid Chromatography Determination and Optimization of the Extraction Process for the Total Alkaloids from Traditional Herb Stephania cepharantha Hayata. Molecules, 24, 388. https://doi.org/10.3390/molecules24030388

[41] Chen, Y., et al. (2016) Total Content Determination for the Effective Fraction of the Alkaloids in Dicranostigma leptopodum (Maxim.) Fedde by HPLC and Ultraviolet-Visible Spectrophotometry. Analytical Methods, 8, 2645-2652. https://doi.org/10.1039/C5AY03054D

[42] Boyer, T.H. and Singer, P.C. (2008) Stoichiometry of Removal of Natural Organic Matter by Ion Exchange. Environmental Science \& Technology, 42, 608-613. https://doi.org/10.1021/es071940n 
[43] Guidechem, $001 \times 7$. https://china.guidechem.com/trade/pdetail16683905.html

[44] Wang, Q. and Wang, J.Y. (2020) Softening of Saline Wastewater by Ion Exchange Resin. Hydrometallurgy of China, 39, 69-73.

[45] Jslhchem. http://www.jslhchem.com/products_b/id/37.html

[46] Liu, W., et al. (2017) Green Synthesis of Carbon Dots from Rose-Heart Radish and Application for $\mathrm{Fe}^{3+}$ Detection and Cell Imaging. Sensors and Actuators B-Chemical, 241, 190-198. https://doi.org/10.1016/j.snb.2016.10.068

[47] Ludmerczki, R., et al. (2019) Carbon Dots from Citric Acid and Its Intermediates Formed by Thermal Decomposition. Chemistry—A European Journal, 25, 11963-11974. https://doi.org/10.1002/chem.201902497

[48] Wang, X., Dai, L., Sun, Z.Q., Gao, P. and Ma, Z.G. (2011) Separation and Purification Technology for Total Alkaloids from Uncariae Ramulus Cum Uncis with Cation Exchange Resin. Chinese Traditional and Herbal Drugs, 42, 1973-1976.

[49] Peng, X.J., Li, S.C., Li, Y.B., Ye, H.Y. and Yu, L. (2014) The Extraction, Separation and Identification of Alkaloids in Leonurus heterophyllus. Research and Exploration in Laboratory, 33, 33-35.

[50] Fan, Q.Y., Zhang, H.H. and Wang, W.H. (2016) Research on Separation and Purification of Alkaloids in Cynoglossum amabile Stapf et Drumm with Resin. Journal of Instrumental Analysis, 35, 1338-1342.

[51] Yan, J.J., et al. (2014) Up-Regulation on Cytochromes P450 in Rat Mediated by Total Alkaloid Extract from Corydalis yanhusuo. BMC Complementary and Alternative Medicine, 14, Article No. 306. https://doi.org/10.1186/1472-6882-14-306

[52] Sun, Z.M., Duan, Z.G., Jiao, L., Zhang, Z.F. and Li, X.N. (2011) Separation and Purification Process of Total Alkaloids from Sinisan. Chinese Journal of Experimental Traditional Medical Formulae, 17, 11-13.

[53] Guo, L.B., Zhou, J.Z. and Zhu, S.S. (2006) Study on Separation and Purification of Total Alkaloids from Herba Ephedrae and Flos Daturae by Macroporous Adsorption Resin. Food and Drug, No. 5, 47-49.

[54] Liang, J.Y., et al. (2019) Carbon Dots-Based Fluorescent Turn Off/On Sensor for Highly Selective and Sensitive Detection of $\mathrm{Hg}^{2+}$ and Biothiols. Spectrochimica Acta Part A: Molecular and Biomolecular Spectroscopy, 222, Article ID: 117260. https://doi.org/10.1016/j.saa.2019.117260

[55] Wang, H.Y., Zhou, Y.N., Takafumi, U., Yamashita, M.Y. and Qian, S.R.G.L. (2016) Isolation and Purifacation of Alkaloid from Holarrhena antidysenterica Wall. ex A. DC. CIESC Journal, 67, 191-196.

[56] Yang, J.J., Chen, Y., Guo, M.L. and Chou, G.X. (2020) Chemical Constituents from the Roots of Lindera aggregata and Their Biological Activities. Journal of Natural Medicines, 74, 441-447. https://doi.org/10.1007/s11418-019-01385-6

[57] Yang, J.J., Chen, Y., Guo, M.L. and Chou, G.X. (2020) Chemical Constituents from the Roots of Lindera aggregata and Their Biological Activities. Journal of Natural Medicines, 74, 441-447. https://doi.org/10.1007/s11418-019-01385-6

[58] Yao, L.C., et al. (2017) Research on Alkaloid Constituents and Quality Standards of Bangga. Asia-Pacific Traditional Medicine, 13, 13-17.

[59] Wang, S.C., Wen, B.Y., Wang, N., Liu, J.T. and He, L.C. (2009) Fluorenone Alkaloid from Caulophyllum robustum Maxim. With Anti-Myocardial Ischemia Activity. Archives of Pharmacal Research, 32, 521-526. https://doi.org/10.1007/s12272-009-1407-7 
[60] Wang, H.X., Ma, C.Y. and Tao, G.J. (2007) Isolation and Purification Technology of Monomeric Alkaloids from Seeds of Sophora alopecuroides L. Journal of Chemical Engineering of Chinese Universities, 21, 194-199.

[61] Yang, J.H., et al. (2020) Carbazole Alkaloids from Clausena Anisum-Olens. Isolation, Characterization, and Anti-HIV Evaluation. Molecules, 25, 99. https://doi.org/10.3390/molecules25010099

[62] Huang, S., et al. (2013) A Novel Steroidal Alkaloid from Fritillaria shuchengensis. Journal of Natural Medicines, 67, 647-651. https://doi.org/10.1007/s11418-012-0702-7

[63] Liang, Z.R., et al. (2012) Separation of Two Quaternary Protoberberine Alkaloids in Corydalis Saxicola Bunting by High-Speed Counter-Current Chromatography Combined with Silica Gel Column Chromatography. Chinese Journal of Analysis Laboratory, 31, 98-101.

[64] Xu, Y., Guo, Z.J. and Wu, N. (2010) Two New Amide Alkaloids with Anti-Leukaemia Activities from Aconitum taipeicum. Fitoterapia, 81, 1091-1093.

[65] Pan, Y.F., Wang, H.M. and Zhang, Y. (2009) Isolation and Purification of Vinblastine and Vincristine from Gatharanthus roseus by Macroporous Adsorption Resin. Chinese Journal of Information on TCM, 16, 51-53.

[66] Dong, L., Zhao, C.X., Yu, Z.M. and Li, F. (2006) Separating a Series of Alkaloids from Sophora alopecuroides Using Silica Fel Column Layer Chromatography. Agrochemicals, No. 4, 256-258.

[67] Yu, L.X., et al. (2014) Understanding Pharmaceutical Quality by Design. The AAPS Journal, 16, 771-783. https://doi.org/10.1208/s12248-014-9598-3

[68] Zhang, N., Lyu, J.F., Bai, P. and Guo, X.H. (2018) Boron Isotopic Separation with Pyrocatechol-Modified Resin by Chromatography Technology: Experiment and Numerical Simulation. Journal of Industrial and Engineering Chemistry, 57, 244-253. https://doi.org/10.1016/j.jiec.2017.08.030

[69] Chen, S., et al. (2017) Separation, Purification, and Characterization of Sterol Fatty Acid Esters from Lotus Plumule. European Journal of Lipid Science and Technology, 119, Article ID: 1700139. https://doi.org/10.1002/ejlt.201700139

[70] Özer, A. (2007) Removal of Pb(II) Ions from Aqueous Solutions by Sulphuric Acid-Treated Wheat Bran. Journal of Hazardous Materials, 141, 753-761. https://doi.org/10.1016/j.jhazmat.2006.07.040

[71] Guo, X. and Wang, J.L. (2019) A General Kinetic Model for Adsorption: Theoretical Analysis and Modeling. Journal of Molecular Liquids, 288, Article ID: 111100. https://doi.org/10.1016/j.molliq.2019.111100

[72] Hu, Y.M., Guo, X., Chen, C. and Wang, J.L. (2019) Algal Sorbent Derived from Sargassum horneri for Adsorption of Cesium and Strontium Ions: Equilibrium, Kinetics, and Mass Transfer. Applied Microbiology and Biotechnology, 103, 2833-2843. https://doi.org/10.1007/s00253-019-09619-Z

[73] Li, Y., Huang, J.H., Liu, J.B., Deng, S.G. and Lu, X.Y. (2013) Adsorption of Berberine Hydrochloride, Ligustrazine Hydrochloride, Colchicine, and Matrine Alkaloids on Macroporous Resins. Journal of Chemical and Engineering Data, 58, 1271-1279. https://doi.org/10.1021/je400057w

[74] Sun, Y., Lin, C.X., Liu, M.H. and Liu, Y.F. (2011) Equilibrium Adsorption Behaviors and Kinetic Characteristics of Oxymatrine on a Spherical Cellulose Adsorbent. Bioresources, 6, 631-640.

[75] Li, Y., Yuan, B., Fu, J., Deng, S.G. and Lu, X.Y. (2013) Adsorption of Alkaloids on 
Ordered Mesoporous Carbon. Journal of Colloid and Interface Science, 408, 181-190. https://doi.org/10.1016/j.jcis.2013.07.037

[76] Guiochon, G. (2002) Preparative Liquid Chromatography. Journal of Chromatography $A$, 965, 129-161. https://doi.org/10.1016/S0021-9673(01)01471-6

[77] Xu, Y.X., Qu, H.B., Chen, Y. and Cheng, Y.Y. (2005) Dynamics of Chromatographic Puerarin Separation Process in Macroporous Resin Column. Journal of Chemical Engineering of Chinese Universities, 19, 751-756.

[78] Pan, J.J., et al. (2019) The Development of an Herbal Material Quality Control Strategy Considering the Effects of Manufacturing Processes. Chinese Medicine, 14, Article No. 38. https://doi.org/10.1186/s13020-019-0262-9

[79] Stirling, R., Morris, P.I. and Grace, J.K. (2015) Prediction of the Decay and Termite Resistance of Western Red Cedar Heartwood. Forest Products Journal, 65, 84-92. https://doi.org/10.13073/FPJ-D-14-00056

[80] Rivera-Mondragon, A., et al. (2019) Phytochemical Characterization and Comparative Studies of Four Cecropia Species Collected in Panama Using Multivariate Data Analysis. Scientific Reports, 9, Article No. 1763.

https://doi.org/10.1038/s41598-018-38334-4

[81] Da Silva, A.R., et al. (2013) Assessment of Total Phenols and Extractives of Mahogany Wood by Near Infrared Spectroscopy (NIRS). Holzforschung, 67, 1-8.

https://doi.org/10.1515/hf-2011-0207 